Sri Lanka J. Aquat. Sci. (2004) 9: 91-108

\title{
Limnology of Kandy Lake before the outbreak of cyanaobacteria bloom in May 1999. II. Photosynthetic primary production
}

\author{
E.I.L. SILVA* AND S.R.M.S. SAMARADIWAKARA \\ Institute of Fundamental Studies, Hantana Road, Kandy, Sri Lanka.
}

*Corresponding Author (E-mail: sil@ifs.ac.lk)

\begin{abstract}
In situ photosynthetic rates and chlorophyll-a contents of planktonic algae were determined monthly for two consecutive years (September 1996 - August 1998) employing light-dark bottle technique in Kandy Lake. The objective of the study was to determine the photosynthetic characteristics and subsequent primary production under prevailing climatic and hydroecological regime of this urban man-made eutrophic water body.

Photosynthesis occurred mainly to a $4 \mathrm{~m}$ depth with light saturated maximum rate at subsurface water under clear sky indicating surface inhibition. Chlorophyll-a (chl-a) content and photosynthetic rates were relatively low during the rainy seasons compared to dry weather conditions. However, both parameters showed a progressive increase towards the end of the study period. With respect to chl-a content $\left(16-45 \mu \mathrm{g} \mathrm{l}^{-1}\right)$ and specific photosynthetic rates (4-42 mg mg ${ }^{-1} \mathrm{chl}^{-\mathrm{a} \mathrm{hr}} \mathrm{h}^{-1}$ ), Kandy lake was eutrophic during the study period. However, area based net primary production was always positive (0.073-1.775 $\left.\mathrm{g} \mathrm{O}_{2} \mathrm{~m}^{-2} \mathrm{hr}^{-1}\right)$ with a daily mean gross value of $9.80 \mathrm{~g} \mathrm{O}_{2} \mathrm{~m}^{-2} \mathrm{~d}^{-1}( \pm 6.20)$.
\end{abstract}

\section{Introduction}

Urban water bodies are susceptible to high anthropogenic pressures from riparian communities and water quality attributes are tied up with hygienic and economic conditions of the surrounding populations. Management of these water bodies is neglected to a great extent in developing countries primarily due to lack of knowledge and financial constraints. Since they receive a variety of untreated effluents (human excreta, agricultural, industrial and domestic wastes etc.), these water bodies are subjected to progressive eutrophication. In addition, chemicals used in amusemert parks, home gardens and lawn care find their way to these water bodies and some times become toxic to aquatic life (Straśkraba and Tundisi 1999). 


\section{E.I.L. Silva \& S.R.M.S. Samaradiwakara}

Hyper-eutrophication and subsequent outbreak of algal blooms with the formation of surface scum in surface water bodies are grave socioeconomic problems of many urban centers in the tropics, which are not facilitated with central sewerage treatment facilities (Silva and Schiemer 2001). Cyanobacteria blooms disturb oxygen balance, secrete toxins of low molecular weight that could be harmful to many aquatic animals including mammals and also cause clogging of gills some fishes (Skulberg et al. 1984; Codd et al. 1989; Carmichael 1992). On the contrary, cyanobacterial blooms are important source of food for some herbivorous fishes (Phillips et al. 1985; Rabergh et al. 1991). Although progressive eutrophic process in water bodies is well understood, timing and magnitude of sudden outbreak of cyanobacteria blooms are still a bizarre (Datta and Jana 1998, 2000, Silva 2003). Schiemer et al. (2001) demonstrated mesotrophic to eutrophic shift with decreasing water level in shallow irrigation reservoirs in Sri Lanka while Silva et al. (2002) found light saturated optimum photosynthetic rates in water bodies with relatively high algal biomass although photosynthetic efficiency or specific photosynthetic rates were high in deep water bodies with low algal biomass. Time series pattern of photosynthetic rates of planktonic algae and their characteristic features in the water column under differential hydro-ecology are good indices of trophic status and trends. Photosynthetic characteristics of pelagic phytoplankton in tropical freshwaters have been demonstrated mainly from Rift Valley lakes in east Africa (see Talling and Lemoalle, 1998). Studies in Sri Lankan freshwaters were primarily confined to irrigation reservoirs (Dokulil et al. 1983; Silva and Davies 1986, 1987; Silva et al. 2002; Amarasinghe and Vjiverberg 2003) and little is known on photosynthetics characteristics of urban water bodies (Khondker and Parveen 1993). The present study was conducted in an urban aesthetic water body i.e., Kandy lake, in Sri Lanka to determine the temporal pattern of photosynthetic characteristics of pelagic phytoplankton and subsequent primary production in relation to hydroecology prevailing under monsoonal weather conditions.

\section{Materials and Methods}

In situ experiments were carried out once a month from September 1996 to August 1998 in the deep basin of Kandy Lake (Silva and Samaradivakara 2004) during the time of peak solar radiation (1100 - 1400 h) to determine the photosynthetic rates at surface, $0.5 \mathrm{~m}, 1 \mathrm{~m}, 2 \mathrm{~m}, 3 \mathrm{~m}$ and $5 \mathrm{~m}$ depths of the euphotic water column using the light-dark bottle technique. Water samples were collected from each depth using a water sampler (Hydro-bios) and seven $125 \mathrm{ml}$ borosilicate bottles were carefully filled with water. One bottle was immediately fixed with Winkler A and B 


\section{Limnology of Kandy Lake}

solutions for the determination of initial oxygen concentration. Three bottles filled with water from the same depth were wrapped with aluminum foil and inserted into light-proof black bags. Three more light bottles were also filled with the same water. The dark bottles and the light bottles were hung at each depth from which the water was obtained to fill the bottles. Bottles were hung perpendicular to the water column on plexiglass tubing tightened sequentially at respective depths on a vertical rope in a mosaic pattern. An additional rope was tightened to a float anchored on the bottom facilitating vertical suspension. Total incoming radiation during the exposure was recorded using a light meter (Dickson Inc. Ltd, USA), calibrated with a quantum sensor (LI-COR, model LI-192S) and the readings $\left(\mathrm{W} \mathrm{m}^{-2}\right)$ were converted into phosynthetically available radiation (PhAR) and expressed in $\mu \mathrm{E} \mathrm{m} \mathrm{m}^{-2} \mathrm{~s}^{-1}$. In addition, Secchi depth was also measured lowering a 20-cm diameter black and white Secchi disk.

Table 1. Abbreviations and symbols used in the text with their respective units.

\begin{tabular}{|c|c|c|}
\hline Symbol & Unit & $\begin{array}{c}\text { Explanation } \\
\end{array}$ \\
\hline PhAR & $\mu \mathrm{E} \mathrm{m}^{-2} \mathrm{~s}^{-1}$ & Photosynthetically available radiation \\
\hline $\mathrm{Z}_{\mathrm{SD}}$ & $\mathrm{m}$ & Secchi depth \\
\hline $\mathrm{Z}_{\mathrm{eu}}$ & $\mathrm{m}$ & Estimated euphotic depth $\left(\mathrm{Z}_{\mathrm{SD}} \times 2.75\right)$ \\
\hline $\mathrm{Z}_{\mathrm{c}}$ & $\mathrm{m}$ & compensation depth \\
\hline $\mathrm{P}_{\text {sur }}$ & $\mathrm{mg} \mathrm{O}_{2} \mathrm{l}^{-1} \mathrm{hr}^{-1}$ & Photosynthetic rate at surface \\
\hline$A_{\max }$ & $\mathrm{mg} \mathrm{O}_{2} \mathrm{I}^{-1} \mathrm{hr}^{-1}$ & $\begin{array}{l}\text { Maximum photosynthetic rate per unite water } \\
\text { volume }\end{array}$ \\
\hline$\sum \mathrm{A}$ & $\mathrm{g} \mathrm{O}_{2} \mathrm{~m}^{-2} \mathrm{hr}^{-1}$ & Area based gross primary productivity per hour \\
\hline$\Sigma \Sigma A$ & $\mathrm{~g} \mathrm{O}_{2} \mathrm{~m}^{-2} \mathrm{~d}^{-1}$ & Area based gross primary productivity per day \\
\hline$\sum N P$ & $\mathrm{~g} \mathrm{O}_{2} \mathrm{~m}^{-2} \mathrm{hr}^{-1}$ & Area based net primary productivity per hour \\
\hline $\bar{\Sigma} \Sigma \mathrm{NP}$ & $\mathrm{g} \mathrm{O}_{2} \mathrm{~m}^{-2} \mathrm{~d}^{-1}$ & Area based net primary productivity per day \\
\hline$\sum \mathrm{R}$ & $\mathrm{g} \mathrm{O}_{2} \mathrm{~m}^{-2} \mathrm{hr}^{-1}$ & Area based respiration per hour \\
\hline $\bar{\Sigma} \Sigma \mathrm{R}$ & $\mathrm{g} \mathrm{O}_{2} \mathrm{~m}^{-2} \mathrm{~d}^{-1}$ & Area based respiration per day \\
\hline & $\mathrm{mg} \mathrm{O}_{2} \mathrm{~m}^{-3} \mathrm{hr}^{-1}$ & Respiration per unit water volume \\
\hline Chl-a & $\mu \mathrm{g} \mathrm{l}^{-1}$ & Chlorophyll-a concentration \\
\hline$\phi_{\max }$ & $\mathrm{mg} \mathrm{mg}^{-1} \mathrm{hr}^{-1}$ & $\mathrm{~A}_{\max } / \mathrm{Chl}-\mathrm{a}$ \\
\hline $\begin{array}{l}S_{\mathrm{pi}} \\
\mathrm{V}: \mathrm{O}\end{array}$ & $\%$ & $\left(A_{\max }-P_{\text {sut }} / A_{\max }\right) \times 100$ \\
\hline
\end{tabular}




\section{E.I.L. Silva \& S.R.M.S. Samaradiwakara}

The same water was processed in the field for laboratory analysis of other related parameters. Three replicates of $250 \mathrm{ml}$ or known volume of water samples from each depth were filtered through Whatman GFC circles and the filter papers wrapped in aluminum foil were preserved immediately in a deep freezer for the determination of chlorophyll-a content (Marker et al. 1980). The initial dissolved oxygen concentration and the dissolved oxygen concentrations of light and dark bottles, after incubation in the field for three hours, were determined using the modified Winkler Technique (HYDRO-BIOS Kiel Dosimat 715 digital titrator). The rate of photosynthesis and community respiration per unit volume of water per hour were integrated over depth (XL Software Package) to obtain corresponding estimates of areabased gross $(\Sigma \mathrm{A})$ and net $(\Sigma \mathrm{NP})$ primary productivity and community respiration $\left(\sum R\right)$ per hour. Subsequently total area based gross and net primary productions ( $\Sigma \Sigma \mathrm{A}$ and $\Sigma \Sigma \mathrm{NP}$ ) per day were calculated by multiplying by factor 10 (Talling and Lemoalle 1998) and also assuming community respiration is constant throughout the day. List of symbols used in the text is given in Table 1 . The phytoplankton primary productivity and related parameters such as $\mathrm{Z}_{\mathrm{uu}}, \mathrm{Z}_{\mathrm{c}}, \mathrm{A}_{\max }, \Sigma \mathrm{A}, \Sigma \sum \mathrm{A}, \Sigma \mathrm{NP}, \Sigma \Sigma \mathrm{NP}, \Sigma \mathrm{R}, \Sigma \Sigma \mathrm{R}, \phi_{\max }$, $\mathrm{S}_{\mathrm{pi}}$ and $\mathrm{A}_{\text {sur }}$ were calculated as defined by Rhode (1958), Talling (1965) and Dokulil et al. (1983). A least square response model was used to determine the correlation between responses and predictor variables.

\section{Results}

Light Climate: Total Incoming Radiation (TIR) ranged from $243 \mathrm{~W} \mathrm{~m}^{-2} \mathrm{~s}^{-1}$ to $1400 \mathrm{~W} \mathrm{~m}^{-2} \mathrm{~s}^{-1}$. In general TIR was high during January, February and March and relatively low during the rainy months. Mean PhAR values during the exposure time were more than $2000 \mu \mathrm{E} \mathrm{m}^{-2} \mathrm{~s}^{-1}$ in February, March and November 1997 and from February to April in 1998. In contrast, PhAR was less than $500 \mu \mathrm{E} \mathrm{m}^{-2} \mathrm{~s}^{-1}$ in September and October 1996, August, September and December 1997, and in January, June, and July 1998. The average TIR during exposure time was more than $1000 \mathrm{~W} \mathrm{~m}^{-2} \mathrm{~s}^{-1}$ at $62 \%$ occasions and it coincided with the dry whether (February to April). The irradiance of TIR was highest around noon and it decreased gradually towards afternoon under clear sky. Similar pattern was observed in the case of $\mathrm{PhAR}$ which was computed as $45 \%$ of the TIR. Figure 1 illustrates the monthly variation of Secchi depth $\left(Z_{S D}\right)$ which was used as a measure of under-water light attenuation. The lowest $Z_{\mathrm{SD}}$ of $55 \mathrm{~cm}$ was recorded in October 1996, and it was more than $100 \mathrm{~cm}$ in other months except in March, May, June, August and October 1997 and in January, June and August 1998. The maximum $Z_{S D}$ of $160 \mathrm{~cm}$ was observed in February 1997 


\section{Limnology of Kandy Lake}

and $Z_{\text {SD }}$ was above $125 \mathrm{~cm}$ from December 1996 to February 1997 and in July and December 1997 (Fig. 1). Euphotic depth (1\% of PhAR) which was approximately estimated by multiplying Secchi depth by a factor of 2.75 , ranged from $151 \mathrm{~cm}$ to $440 \mathrm{~cm}$ with a mean value around $300 \mathrm{~cm}$. The compensation depth $\left(Z_{c}\right)$ where the community respiration was equal to photosynthesis oxygen production ranged from $170 \mathrm{~cm}$ to $550 \mathrm{~cm}$ with an average value of $330 \mathrm{~cm}$.

Chlorophyll-a: The chl-a content which is an index of phytoplankton biomass in the surface water ranged from $16 \mu \mathrm{g} \mathrm{l}^{-1}$ to $45 \mu \mathrm{g} \mathrm{l}^{-1}$ with a mean value of $23 \mu \mathrm{g} \mathrm{l}^{-1}( \pm 4.66)$ during the study period. During dry months (February-March), chl-a was high and low concentrations were recorded during wet months (December-January). The chl-a concentrations were significantly different between dry months and wet months $(\mathrm{t}=3.01 ; \mathrm{p}=$ 0.006 , df $=21$ ). Although chl-a concentration showed a negative relationship with monthly rainfall, it was statistically not significant $(r=$ $0.316 ; \mathrm{p}=0.131$ ). Chl-a concentration in surface and bottom water at deep basin of Kandy Lake is shown in Figure 2. In surface water, the lowest value of $16 \mu \mathrm{g} \mathrm{l}^{-1}$ was found in December 1.996 and it was below $20 \mu \mathrm{g} \mathrm{l}^{-1}$ only from December 1996, to March 1997 . The highest value of $45 \mu \mathrm{g} \mathrm{I}^{-1}$ was recorded in September 1997 and it was above $30 \mu \mathrm{g} \mathrm{l}^{-1}$ in from January to August 1998. In the case of the bottom water in the deep basin, the lowest value of $5 \mu \mathrm{g} \mathrm{l}^{-1}$ was recorded in October 1996, in May 1997 and in August 1998. Moreover, it was less than $10 \mu \mathrm{g} \mathrm{l}^{-1}$ only at seven occasions. The highest value of $27 \mu \mathrm{g} \mathrm{l}^{-1}$ was found in June 1998. In general, the chl-a concentration in bottom water was less than that in surface water; however in January and February 1997, the concentrations in bottom water were more or less similar to those in surface water. Significantly negative relationship was found between $Z_{S D}$ and chl-a for Kandy Lake only during dry and less rainy months.

Figure 3 depicts the vertical distribution pattern of mean chl-a values at the deep basin of Kandy Lake. The maximum mean concentration of $27 \mu \mathrm{g} \mathrm{l}^{-1}( \pm 9)$ occurred at 2-m depth while the minimum of $14 \mu \mathrm{g} \mathrm{l}^{-1}$. $( \pm$ 9) was recorded at the bottom layer. Although chl-a concentration increased from surface to $2 \mathrm{~m}$ depth, it decreased at $3 \mathrm{~m}$ and slightly increased again at $4 \mathrm{~m}$ depth demonstrating a bimodal vertical distribution pattern.

Photosynthetic characteristics and related parameters during each sampling event are given in Table 2 . Six selected depth profiles (depth vs oxygen production per hour) representing three weather conditions (wet, moderately wet and dry) are illustrated in Figure 4. A majority of the depth profile exhibits surface inhibition and in most cases light saturated maximum photosynthetic rate occurred $\left(A_{\max }\right)$ at $0.5 \mathrm{~m}$ below the surface. Surface photoinhibition was more than $30 \%$ under dry weather condition but low values were computed under overcast conditions. The highest value 


\section{E.I.L. Silva \& S.R.M.S. Samaradiwakara}

of $\mathrm{A}_{\max }$ of $1.705 \mathrm{mg} \mathrm{O}_{2} \mathrm{I}^{-1} \mathrm{hr}^{-1}$ was determined for the surface layer in July 1998 and the lowest $\mathrm{A}_{\max }$ was $0.11 \mathrm{mg} \mathrm{O}_{2} \mathrm{I}^{-1} \mathrm{hr}^{-1}$ in August 1997 at $0.5 \mathrm{~m}$ depth. Mean value of $\mathrm{A}_{\max }$ was $0.54 \mathrm{mg} \mathrm{O}_{2} \mathrm{l}^{-1} \mathrm{hr}^{-1}( \pm 0.40)$ during the study period. Specific photosynthetic rate or the rate per unit chl-a content $\left(\phi_{\max }\right)$ was lowest ( $\left.4 \mathrm{mg} \mathrm{mg}^{-1} \mathrm{hr}^{-1}\right)$ in August 1997. This was observed under heavy rainy condition. However, the highest $\phi_{\max }$ value of $42 \mathrm{mg} \mathrm{mg}^{-1} \mathrm{hr}^{-1}$ was observed in August 1998 when $\mathrm{A}_{\max }$ was also highest. Figure 5 shows monthly variation of $A_{\max }$ and $\phi_{\max }$ during the study period. $A_{\max }$ and $\phi_{\max }$ do not show a marked seasonal pattern. $A_{\max }$ value was more than $0.50 \mathrm{mg} \mathrm{O} \mathrm{O}_{2}$ $\mathrm{l}^{-1} \mathrm{hr}^{-1}$ during eight occasions of which five occasions occurred during the

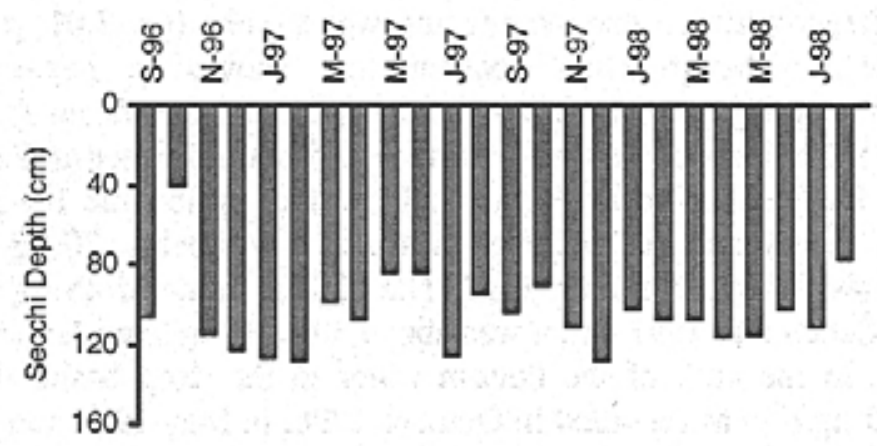

Figure 1. Monthly mean values of Secchi depth $\left(\mathrm{Z}_{\mathrm{SD}}\right)$ of Kandy Lake during the study period.

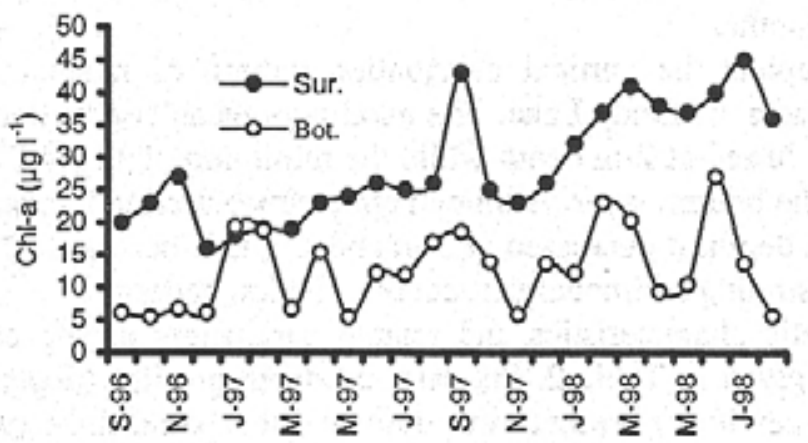

Figure 2. Monthly values of Chl-a concentration in surface and bottom water at the deep basin of Kandy Lake during the study period. 


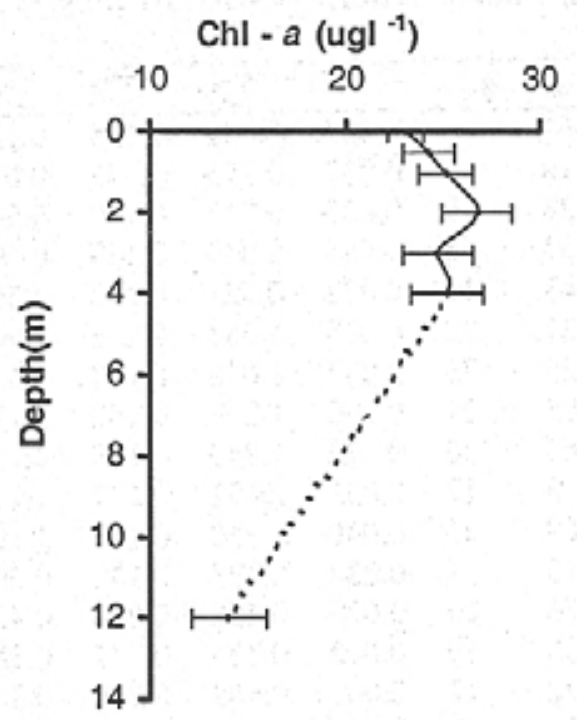

Figure 3. Depth profile of mean Chlorophyll- $a$ concentrations of Kandy Lake at the deep basin. Horizontal lines denote the standard error.

second year of the study. Further, $\mathrm{A}_{\max }$ was more than $1.00 \mathrm{mg} \mathrm{O}_{2} \mathrm{I}^{-1} \mathrm{hr}^{-1}$ in March 1998 and during the last two occasions of the study. $\phi_{\max }$ value was more than $25 \mathrm{mg} \mathrm{mg}^{-1} \mathrm{hr}^{-1}$ only during four occasions i.e., two occasions during each year. The relationship of $\log \phi_{\max }$ vs chl-a was negative but was not statistically significant at $p=0.05$. Monthly variations of $\phi_{\max }$ and chl-a at the depth of the $A_{\max }$ during the study period are shown in Figure 6. Figure 6 does not show a marked seasonal pattern either in $\phi_{\max }$ or chl-a content.

Community respiration: The rate of community resiration ( $\mathrm{R})$ in Kandy lake during the study period ranged from $0.020 \mathrm{mg} \mathrm{O}_{2} \mathrm{I}^{-1} \mathrm{hr}^{-1}$ to $0.298 \mathrm{mg} \mathrm{O}_{2} \mathrm{I}^{-1}$ $\mathrm{hr}^{-1}$ with a mean value of $0.07 \mathrm{mg} \mathrm{O}_{2} \mathrm{I}^{-1} \mathrm{hr}^{-1}$. Community respiration was also relatively higher during the dry month when compared with the rainy months. Although respiration was more or less similar in the water column down to $4.5 \mathrm{~m}$ depth there were instances of depth specific high respiration rates (Fig. 4). The mean value of area-based community respiration $\left(\sum R\right)$ was $0.311 \mathrm{~g} \mathrm{O}_{2} \mathrm{~m}^{-2} \mathrm{hr}^{-1}( \pm 0.059)$ and it varied between $0.076 \mathrm{~g} \mathrm{O}_{2} \mathrm{~m}^{-2} \mathrm{hr}^{-1}$ and $1.19 \mathrm{~g} \mathrm{O}_{2} \mathrm{~m}^{-2} \mathrm{hr}^{-1}$. The rate of community respiration during each incubation is given in Table 2. Community respiration was more than 0.03 $\mathrm{mg} \mathrm{O}_{2} \mathrm{I}^{-1} \mathrm{hr}^{-1}$ only one occasion in the first year of the study, while it was always less than $0.03 \mathrm{mg} \mathrm{O}_{2} \mathrm{I}^{-1} \mathrm{hr}^{-1}$ only once during the second year of the 


\section{E.I.L. Silva \& S.R.M.S. Samaradiwakara}

Table 2. Photosynthetic characteristics and related parameters of Kandy Lake. (Descriptions and abbreviations of symbols are given in Table 1).

\begin{tabular}{lrrrrrrrrr}
\hline Date & Chl-a & $\mathrm{A}_{\max }$ & $\phi_{\max }$ & $\mathrm{R}$ & $\sum \mathrm{A}$ & $\sum \mathrm{R}$ & $\sum \mathrm{NP}$ & $\mathrm{S}_{\mathrm{pi}}$ & $\mathrm{V}: \mathrm{O}$ \\
\hline S-96 & 20 & 0.162 & 8 & 0.038 & 0.288 & 0.155 & 0.133 & 36 & 1.78 \\
O-96 & 23 & 0.210 & 9 & 0.037 & 0.215 & 0.142 & 0.073 & 0 & 1.02 \\
N-96 & 27 & 0.328 & 12 & 0.033 & 0.672 & 0.129 & 0.543 & 51 & 2.05 \\
$\mathrm{D}-96$ & 16 & 0.257 & 16 & 0.034 & 0.634 & 0.139 & 0.495 & 45 & 2.47 \\
$\mathrm{~J}-97$ & 18 & 0.347 & 19 & 0.033 & 0.725 & 0.132 & 0.593 & 35 & 2.09 \\
$\mathrm{~F}-97$ & 19 & 0.427 & 22 & 0.038 & 1.087 & 0.145 & 0.942 & 20 & 2.55 \\
M-97 & 19 & 0.625 & 33 & 0.037 & 1.688 & 0.150 & 1.537 & 31 & 2.70 \\
A-97 & 23 & 0.493 & 21 & 0.035 & 1.257 & 0.142 & 1.115 & 6 & 2.55 \\
M-97 & 24 & 0.863 & 36 & 0.032 & 1.840 & 0.125 & 1.715 & 4 & 2.13 \\
J-97 & 26 & 0.443 & 17 & 0.033 & 0.892 & 0.137 & 0.755 & 0 & 2.01 \\
J-97 & 25 & 0.569 & 23 & 0.040 & 1.350 & 0.158 & 1.192 & 21 & 2.37 \\
A-97 & 26 & 0.113 & 4 & 0.034 & 0.223 & 0.132 & 0.091 & 24 & 1.97 \\
S-97 & 43 & 0.676 & 16 & 0.020 & 0.498 & 0.076 & 0.422 & 0 & 0.74 \\
O-97 & 25 & 0.485 & 19 & 0.092 & 0.763 & 0.377 & 0.386 & 0 & 1.57 \\
N-97 & 23 & 0.272 & 12 & 0.065 & 0.608 & 0.246 & 0.362 & 0 & 2.24 \\
D-97 & 26 & 0.311 & 12 & 0.062 & 0.384 & 0.254 & 0.130 & 0 & 1.23 \\
J-98 & 32 & 0.276 & 9 & 0.148 & 0.851 & 0.601 & 0.249 & 2 & 3.08 \\
F-98 & 37 & 0.304 & 8 & 0.084 & 0.569 & 0.325 & 0.245 & 13 & 1.87 \\
M-98 & 41 & 1.08 & 26 & 0.129 & 1.691 & 0.489 & 1.202 & 36 & 3.70 \\
A-98 & 38 & 0.636 & 17 & 0.102 & 1.521 & 0.412 & 1.108 & 39 & 2.39 \\
M-98 & 37 & 0.402 & 11 & 0.067 & 0.828 & 0.271 & 0.557 & 0 & 2.06 \\
J-98 & 30 & 0.486 & 16 & 0.126 & 0.567 & 0.479 & 0.088 & 0 & 1.17 \\
J-98 & 45 & 1.705 & 38 & 0.298 & 2.775 & 1.190 & 1.586 & 0 & 1.63 \\
A-98 & 36 & 1.521 & 42 & 0.249 & 1.680 & 1.062 & 0.618 & 38 & 1.10 \\
\hline
\end{tabular}

study. Community respiration was relatively high and more than $0.20 \mathrm{mg}$ $\mathrm{O}_{2} \mathrm{I}^{-1} \mathrm{hr}^{-1}$ towards the end of the study period (Table 2).

Net and gross production: Table 2 gives monthly variation of area based gross primary production and corresponding community respiration of Kandy Lake during the study period. The area-based values were obtained by depth integration of photosynthetic rate and community respiration. The area based gross primary production rate $(\Sigma \mathrm{A})$ ranged from $0.215 \mathrm{~g} \mathrm{O}_{2} \mathrm{~m}^{-2}$ $\mathrm{hr}^{-1}$ to $2.775 \mathrm{~g} \mathrm{O}_{2} \mathrm{~m}^{-2} \mathrm{hr}^{-1}$ with a mean value of $0.98 \mathrm{~g} \mathrm{O}_{2} \mathrm{~m}^{-2} \mathrm{hr}^{-1}( \pm 0.62)$. $\sum \mathrm{A}$ was less than $0.3 \mathrm{~g} \mathrm{O}_{2} \mathrm{~m}^{-2} \mathrm{hr}^{-1}$ in September and October 1996 and August 1997 and more than $0.5 \mathrm{~g} \mathrm{O}_{2} \mathrm{~m}^{-2} \mathrm{hr}^{-1}$ during the rest of the study period except in September and December 1997 (Table 2). Further, $\Sigma A$ was more than $1.00 \mathrm{~g} \mathrm{O}_{2} \mathrm{~m}^{-2} \mathrm{hr}^{-1}$ at nine occasions during the study period. $\sum \mathrm{A}$ was less during north east monsoonal months in both years. Net primary production $\left(\sum \mathrm{NP}\right)$ calculated per unit area using $\sum \mathrm{A}$ and $\sum \mathrm{R}$ values ranged from $0.073 \mathrm{~g} \mathrm{O}_{2} \mathrm{~m}^{-2} \mathrm{hr}^{-1}$ to $1.715 \mathrm{~g} \mathrm{O}_{2} \mathrm{~m}^{-2} \mathrm{hr}^{-1}$ with a mean value of $0.67 \mathrm{~g}$ 
Limnology of Kandy Lake
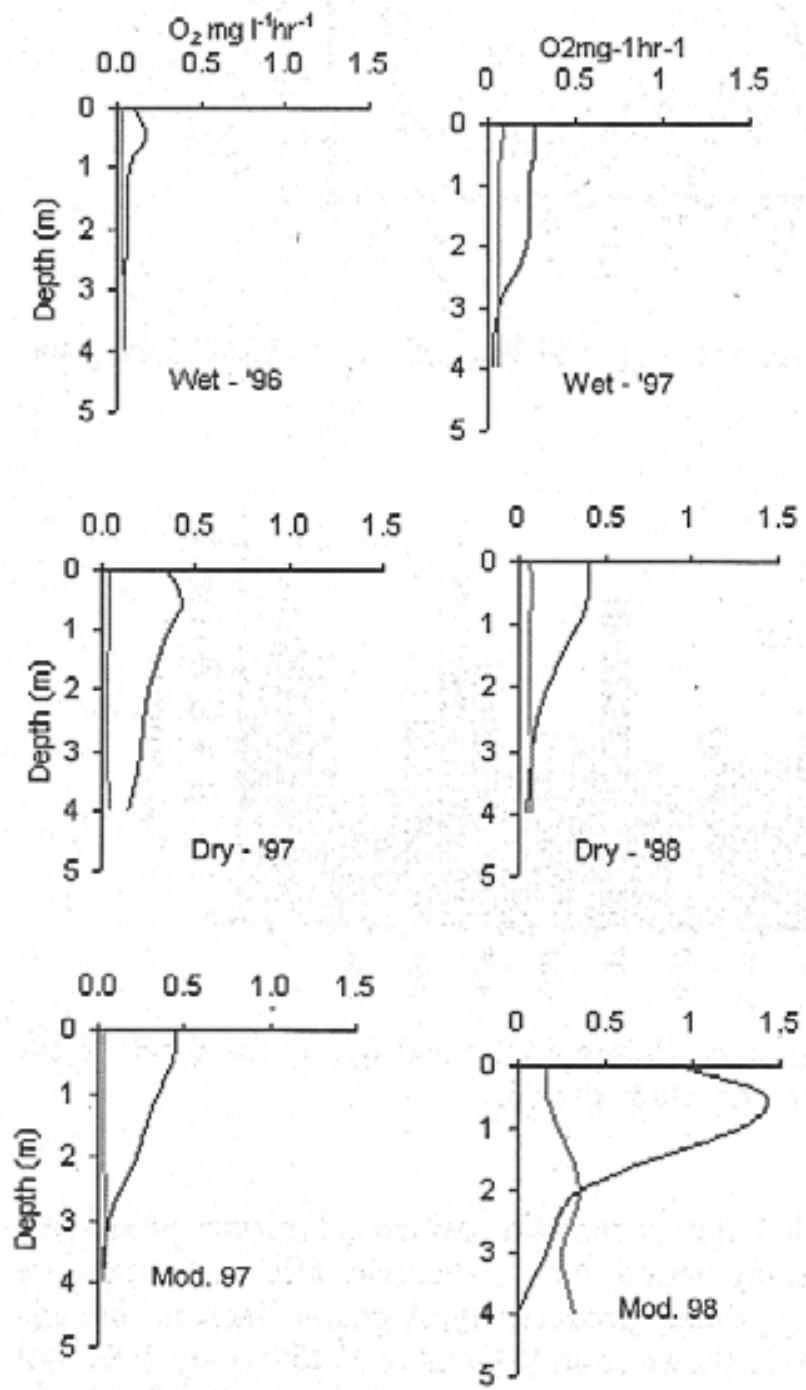

Figure 4. Selected depth profiles of photosynthetic rate (outer liner) and community respiration (inner liner) representing wet dry and moderately wet (Mod.) weather conditions. 


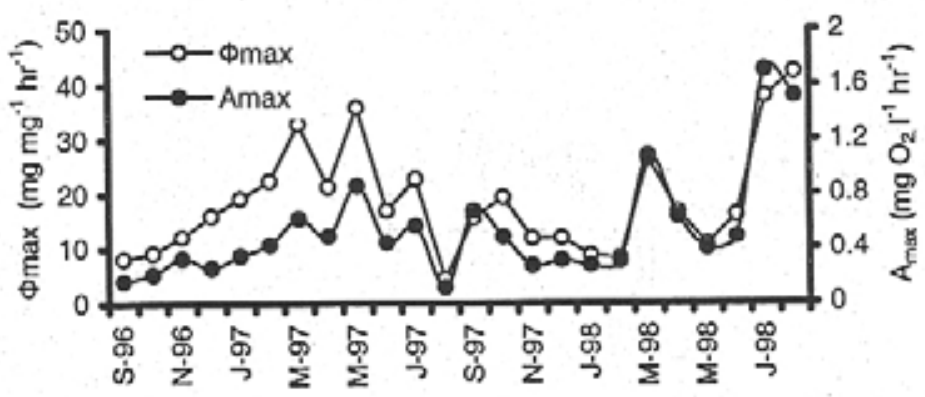

Figure 5. Monthly variation of $\mathrm{A}_{\max }$ and $\phi_{\max }$ of Kandy Lake during the study period.

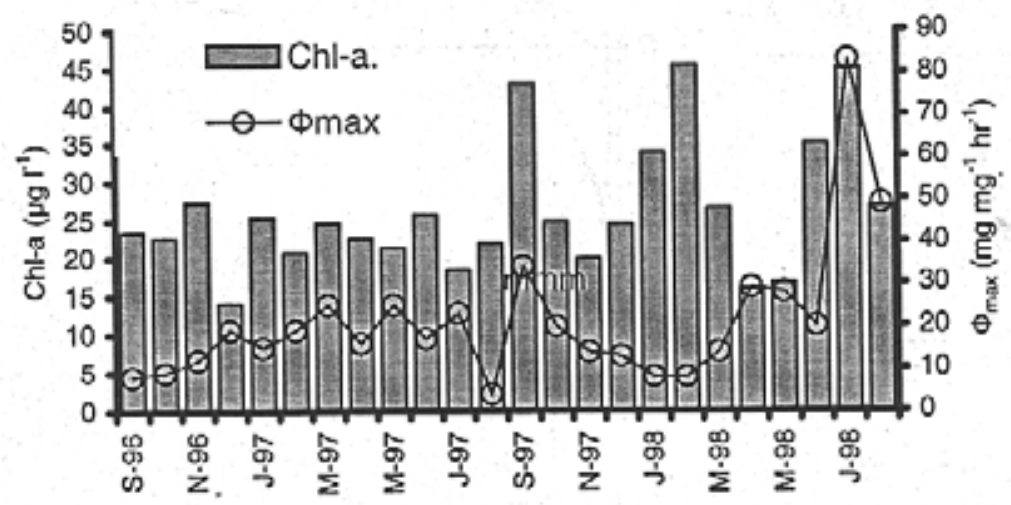

Figure 6. Monthly variation of Chlorophyll- $a$ and $\phi_{\max }$ at the depth of the $\mathrm{A}_{\max }$ of Kandy Lake during the study period.

$\mathrm{O}_{2} \mathrm{~m}^{-2} \mathrm{hr}^{-1}( \pm 0.51)$. Table 2 further shows a positive net primary production in Kandy Lake during study period. Net productivity also shows more or less similar trend to gross primary productivity. A gradual increase in daily gross primary production is shown from September 1996 to May 1997, but the values were relatively low during August and September 1997. An increasing trend in daily production is shown again during 1998 with the highest daily value of $27.75 \mathrm{~g} \mathrm{O}_{2} \mathrm{~m}^{-2} \mathrm{~d}^{-1}$ in July 1998 . Figure 7 shows the relationship between light saturated maximum photosynthetic rate and area based gross primary production. This positive relationship is highly significant and the ratio of optimal photosynthesis per unit volume to column photosynthesis per unit area $(\mathrm{V}: \mathrm{O})$ ranged between 0.074 and 3.7 (Table 2). 


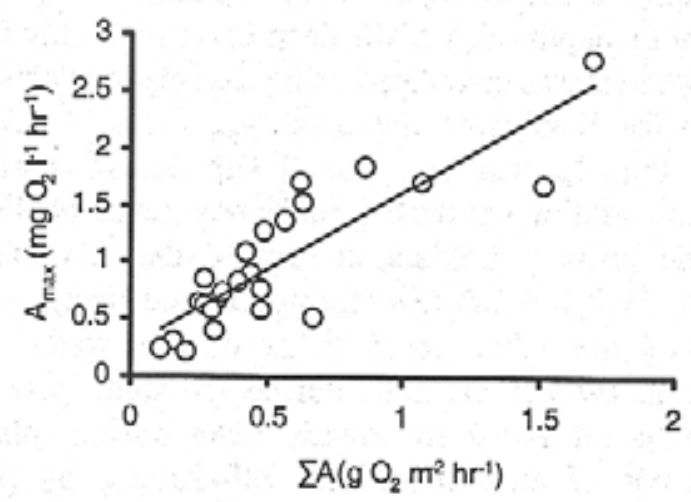

Figure 7. Relationship between area based gross primary production per hour $(\Sigma A)$ and maximum photosynthetic rate per hour $\left(\mathrm{A}_{\max }\right)\left(\mathrm{r}^{2}=0.743 ; \mathrm{p}\right.$ $=0.000$ ).

\section{Discussion}

The range of PhAR recorded at Kandy Lake during the study period was wider and the incidences of low mean values of PhAR during the incubation were higher than the values reported by Dokulil et al. (1983) for Parakrama Samudra. Relatively low incidence of PhAR on Kandy Lake could be attributed to the cloud cover, which is common at higher altitudes in the wet zone of the country. Silva et al. (2002) reported a relatively wide

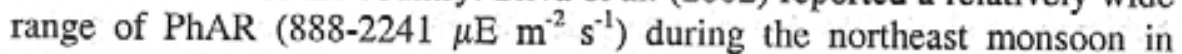
eleven irrigation reservoirs located island-wide. Irrespective of monsoon driven seasons, incidence of $\mathrm{PhAR}$ on Kandy Lake showed intermittent fluctuations. However, $\mathrm{PhAr}$ impinging on surface water was sufficient to occur light saturated maximum photosynthesis $\left(A_{\max }\right)$ in the lake except for a few instances.

Secchi depth value, which is an indirect approximation of euphotic depth indicates a relatively high vertical extinction coefficient in Kandy Lake although there were instances of extremely low $Z_{S D}$ values at the beginning established from inflow to outflow when sampling was carried out following a rainy day. Underwater light extinction was also affected by phytoplankton densities of the water body. This is evident from the negative relationship between $Z_{S D}$ and chl-a content of Kandy Lake during dry and less rainy months. Low $Z_{S D}$ values during dry months may be attributed to high density of phytoplankton and the overall decreasing trend during the study period may be an indication of progressive eutrophication. The 


\section{E.I.L. Silva \& S.R.M.S. Samaradiwakara}

variation in light extinction in Kandy Lake may be attributed to increased light absorption and scattering by dense populations of phytoplankton.

Euphotic depth $\left(\mathrm{Z}_{\mathrm{eu}}\right)$ of the deep basin of Kandy Lake was confined up to $4.4 \mathrm{~m}$ when it was calculated using the relationship derived by Dokulil et al. (1983) for Parakrama Samudra $\left(Z_{\mathrm{eu}}=\mathrm{Z}_{\mathrm{SD}} * 2.75\right)$. However, the results show that $Z_{\mathrm{eu}}$ was less than $3.0 \mathrm{~m}$ during most of the study the period. Recent studies conducted in Kandy Lake on light condition and photosynthetic primary production showed the relationship between $Z_{S D}$ and $Z_{\mathrm{wu}}$ as $\mathrm{Z}_{\mathrm{eu}}=\mathrm{Z}_{\mathrm{SD}} * 2.5$ (Silva, unpublished data). Accordingly, in the deep basin of the lake, about $8 \mathrm{~m}$ of the water column remained unproductive as the aphotic zone during the study period. Relatively low euphotic depths estimated for Kandy Lake during this study may be a combined result of absorption and self-shading by phytoplankton and scattering by inorganic particles (Silva et al. 2002). A significant relationship between $Z_{\mathrm{SD}}$ and chl-a which occurred only in dry and moderately rainy months, indicates that Kandy Lake had more or less similar densities of phytoplankton in the euphotic zone at the deep basin which can be affected by sediment loading resulting from heavy rains.

Relatively high chl-a content in the water body during dry months indicates high growth of planktonic algae as a result of photosynthetic efficiency whereas a decrease in chl-a during the rainy months is essentially an outcome of dilution and biomass loss through the outflow. The lake spills over only during the rainy season. The concentration of chl-a in the lake was above eutrophic level throughout the study period according to the classification of water bodies by Dillon and Rigler (1974). This situation in Kandy Lake is different from those of other water bodies in Sri Lanka such as deep upland reservoirs and lowland shallow irrigation reservoirs. Schiemer et al. (2001) showed a trophic shift in lowland shallow irrigation reservoirs from rainy season to dry season with respect to chl-a content, while chl-a content in the deep upland reservoirs remains more or less constant throughout the year. This indicates a steady eutrophic nature of Kandy Lake during the period of investigation, which may lead to a hypereutrophic condition. The occurrence of chl-a in the aphotic zone although in lesser amounts indicates wind mixing circulation of algal biomass. Certain cyanobacteria such as, Microcystis spp. are capable of sinking down to the lower layers in the night and buoying during daytime. Further, a higher abundance of Merismopedia spp. was observed in the bottom layers of the Kandy Lake (Silva and Samaradiwakara, unpublished data). However, certain phytoplankton species are physiologically adapted to be in dark conditions for a prolonged period of time (Reynolds 1984). Surface inhibition, essentially a light induced diel phenomenon (Harris 1978) was characteristic of a majority of the photosynthetic profiles derived from the light and dark bottle experiment in the Kandy Lake. The occurrence of subsurface maxima around noon (Dokulil et al. 1983; Silva 


\section{Limnology of Kandy Lake}

and Davies 1986, 1987; Silva et al. 2002) during the study period suggests that surface photoinhibition, which is a light induced ecophysiological phenomenon common in tropical freshwaters, occurs also in Kandy Lake. Subsurface PhAR intensity should exceed $900 \mu \mathrm{E} \mathrm{m} \mathrm{m}^{-2} \mathrm{~s}^{-1}$ for surface inhibition to occur (Dokulil et al. 1983); but it varies according to the reservoir and the lower and upper limits are $200 \mu \mathrm{E} \mathrm{m}^{-2} \mathrm{~s}^{-1}$ and $2200 \mu \mathrm{E} \mathrm{m}$ $\mathrm{s}^{-1}$ respectively (Harris 1978). However, there have been instances where the surface maximum occurred when subsurface PhAR intensities were well above the photoinhibition threshold, which results due to ecophysiological adaptation of the phytoplankton populations (Vincent 1979; Ward and Wetzel 1980). Such instances were evident in vertical profile of the Kandy Lake during this study. Although Silva and Davies (1987) have shown a monsoon bound seasonal pattern in surface inhibition in dry zone irrigation reservoirs such a pattern was not prominent in the Kandy Lake. However, the percentage surface inhibition was markedly high under dry weather conditions. A wide range of $A_{\max }$ may be attributed to several factors such as PhAR, nutrient contents, algal biomass, etc. Non-significant relationship between chl-a and $A_{\max }$ is a good indicator of multi-factorial effects on light saturated photosynthetic efficiency. The upper values are within the range reported for Parakrama Samudra under extremely low water level conditions in 1979 by Dokulil et al. (1983). The lower limits were within the range reported by several workers for different types of surface water bodies in Sri Lanka (Silva and Davies 1986, 1987; Silva et al. 2002).

The values for $\Phi_{\max }$ were within the range reported for other tropical freshwater bodies (Talling and Lemoalle, 1998). Maximum $\Phi_{\max }$ of $42 \mathrm{mg} \mathrm{mg}^{-1} \mathrm{hr}^{-1}$ was found during this study for a chl-a value of $36 \mu \mathrm{g} \mathrm{l}^{-1}$. Silva et al. (2002) reported $\Phi_{\max }$ value of $46 \mathrm{mg} \mathrm{mg}^{-1} \mathrm{hr}^{-1}$ for Chandrikawewa for a corresponding chlorophyll- $a$ value of $6 \mu \mathrm{g} \mathrm{l}^{-1}$. The variation of the intrinsic shape of the photosynthetic profiles of the Kandy Lake may be attributed to several factors. The shape of the profile is primarily determined by light climate in shallow water bodies. When stratification of algal biomass is confined mainly to the upper layer, photosynthetic rate may be modified resulting in irregular shapes of vertical profiles (Talling 1965; Dokulil et al. 1983). Silva and Davies (1986) reported bi-model photosynthetic profiles for Parakrama Samudra and Pimburettewa reservoirs during afternoon hours. Bi-modal photosynthetic profiles, in thermally stratified lakes have been explained in terms of changes in the light regime and ecophysiological adaptations of phytoplankton. Bi-modal photosynthetic profiles found in Kandy Lake may be a result of either ecophysiological adaptation of phytoplankton or changes in light regime. The variation in compensation depth where photosynthetic rate is balanced by the respiration was compatible with the euphotic depth in Kandy Lake and the decreasing nature of both euphotic 


\section{E.I.L. Silva \& S.R.M.S. Samaradiwakara}

and compensation depths during the last two months of the study period indicates an increasing nature of eutrophic status.

The range of the rate of community respiration and its magnitude relative to photosynthetic rate was wide in the Kandy Lake compared to that of tropical waters (Thornton 1990; Talling and Lamoalle 1998). In a situation dominated by autotrophs, the ratio of respiration to light saturated photosynthesis in the tropics is $0.05-0.1 \mathrm{mg} \mathrm{O}_{2} \mathrm{I}^{-1} \mathrm{hr}^{-1}$ and corresponding absolute specific rate of $\Phi_{\max }$ is $1 \mathrm{mg} \mathrm{mg}^{-1} \mathrm{hr}^{-1}$ (Talling 1965; Ganf 1974; Lemoalle 1983). Silva et al. (2002) observed exceptionally high oxygen consumption and negative net primary production in some Sri Lankan reservoirs with high algal biomass. In Kandy Lake, the potential value of respiration to $A_{\max }$ ranged from 0.02 to $0.174 \mathrm{mg} \mathrm{O}_{2} \mathrm{l}^{-1} \mathrm{hr}^{-1}$ during the period under investigation. Ganf and Blazka (1974) reported high oxygen consumption by zooplankton in Lake George in Uganda. Oxygen consumption by heterotrophic organisms is high in waters with considerable input of organic matter. Similar trends were reported in flood plain water of the Amazon River (Wissamar et al. 1981) and in Parakrama Samudra during low water level (Dokulil et al. 1983). High oxygen consumption in Kandy Lake may be mainly due to high densities of heterotrophic bacteria (Sharaff 2003) as the zooplankton densities in this water body are relatively low (Silva et al. 2003).

Negative net primary production was not observed in Kandy Lake when oxygen consumption was integrated up to the estimated euphotic depth. If it was calculated for the entire water column, certainly there will be negative net primary production. Negative production suggests that nutrient limitation for phytoplankton growth be replaced by the light limitation (Carig̉nan and Planas 1994). Khondker and Parveen (1993) reported high photosynthetic capacity during a seasonal (monsoonal) low abundance of phytoplankton in an oxbow lake in Bangladesh. Net primary production was high in Kandy Lake as reported for some Indian water bodies (Ganapati and Sreenivasan 1970). The highest $\Sigma \Sigma N P$ in Kandy Lake was $17.2 \mathrm{~g} \mathrm{O}_{2} \mathrm{~m}^{-2} \mathrm{~d}^{-1}$, which is much higher than the value reported for Sri Lankan water bodies (Dokulil et al. 1983; Silva and Davies 1986, 1987; Silva et al. 2002). A significant relationship between area based gross primary production $(\Sigma \mathrm{A})$ and optimum light saturated production rate was found in the present study as reported for other tropical water bodies (Talling 1965; Gliwicz 1976; Robarts 1979; Lemoalle 1979, 1981; Erikson et al. 1991; Khondker and Parveen 1993; Mukankomeje et al. 1993; Silva et al. 2002). V/O ratio (Rhode 1958), gross primary production per unit area and the light saturated photosynthetic rate in Kandy Lake were within the range of previously reported values for Sri Lankan fresh water bodies (Dokulil et al. 1983; Silva and Davies 1987; Silva et al. 2002). 


\section{Limnology of Kandy Lake}

\section{Acknowledgements}

This study was funded by the Institute of Fundamental Studies. We are thankful to Mr. Namal P. Athukorala for his continuous assistance in the field as well as in laboratory analysis. We are also thankful to Mrs. G.A.R.K. Gamlath and Ms. I. Thumpela for their assistance in the field and laboratory.

\section{References}

Amarasinghe, P.B. \& J. Vijverberg 2003.

Primary production in a tropical reservoir in Sri Lanka. Hydrobiologia 487: 85-93.

Carignan, R. \& D. Planas 1994.

Recognition of nutrient and light limitation in turbid mixed layers. Three approaches compared in the Parana floodplain (Argentina). Limnology and Oceanography 39: 439-443.

Carmichael, W. W. 1992.

Cyanobacteria secondary metabolites - the cyanotoxins. Journal of Applied Bacteriology 72: 445-459.

Codd, G. A., W. P. Brooks, L. A. Lawton, \& K. A. Beattie 1989. Cyanobacterial toxins in European waters: occurrence, properties, problems and requirements. In: 'Watershed' 89. The Future for Water Quality in Europe. Vol. 2, (D. Wheeler, M. J. Rrichardson \& J. Bridges eds). pp. 211-220, Pergamon Press, Oxford.

Dillon, P. \& R.H. Rigler 1974.

A test of a simple nutrient budget model predicting the phosphorous concentration in lake water. Journal of Fisheries Research Board Canada 31: 1771-1778.

Dokulil M., K. Bauer \& E.I.L. Silva 1983.

An assessment of the phytoplankton biomass and primary productivity of Parakrama Samudra, a shallow man-made lake in Sri Lanka. In: Limnology of Parakrama Samudra - Sri Lanka: A Case Study of an Ancient Man-made Lake in the Tropics (F. Scheimer ed.). pp. 49-76, Developments in Hydrobiology 12. Dr. W. Junk Publishers, The Hague.

Ganapati, S.V. \& A. Sreenivasan 1970.

Energy flow in natural aquatic ecosystems in India. Archiv für Hydrobiologie 66: 458-98.

Ganf, G.G. 1974.

Phytoplankton biomass and distribution in a shallow eutrophic lake (Lake George, Uganda). Oecologia 16: 9-29. 
Ganf, G.G. \& P. Blazka 1974.

Oxygen uptake, ammonia and phosphate excretion by zooplankton of a shallow equatorial lake (Lake George, Uganda). Limnology and Oceanography 19: 313-325.

Harris, G.P. 1978.

Photosynthesis, productivity and growth: the physiological ecology of phytoplankton. Archiv fur Hydrobiologie 10: 1-171.

Khondker, M. \& L. Parveen 1993.

Daily rate of primary productivity in hypertrophic Dhamondi Lake. In: Hypertrophic and Polluted Freshwater Ecosystems: Ecological bases for water resources management (M.M. Tilzer \& M. Khondker eds). pp. 181-191, Bangladesh Department of Botany, University of Dhaka.

Lemoalle, J. 1983.

Phytoplankton Production. In: Lake Chad. Ecology and Productivity of a Shallow Tropical Ecosystems (J.P Carmouse, J.R. Durand \& C. Leveque eds). pp. 357-384, Monographie Biologicae Vol. 53, W. Junk Publishers, The Hague.

Marker, A.F.H., C.A. Crowther \& J.M. Gunn 1980.

Methanol and acetone as solvents for estimating chlorophyll-a and phaeopigments by spectrophotometry. Archiv für Hydrobiologie (Supplement) 14: 52-69.

Mukankomeje, R., P.D. Plisner, J.P. Descy \& L. Massault 1993.

Lake Muzahi, Ruwanda limnological features and phytoplankton production. Hydrobiologia 257: 107-120.

Phillips, M.J., R.J Roberts, J.A. Stewart \& G.A. Codd 1985.

The toxicity of the cyanobacterium Microcystis aeruginosa to rainbow trout Salmo gairdneri Richardson. Journal of Fish Diseases 8: 399-344.

Rabergh, C.M.I., G. Bylund \& J.E. Eriksson 1991.

Histopathological effects of microcystin-LR, acyclic peptide toxin from the cyanobacterium (blue-green alga) Microcystis aeruginosa, on common carp. Aquatic Toxicology 20: 131-146.

Reynolds, C.S. 1984.

The Ecology of Freshwater Phytoplankton. Cambridge University Press, Cambridge.

Rhode, W. 1958.

Primärproduktion and Seentypen. Internationale Vereinigung für Theoretische und Angewandte Limnologie 13: 121-141.

Robarts, R.D. 1979.

Underwater light penetration, chlorophyll- $a$ and primary production in a tropical African Lake (Lake McIlwaine, Rhodesia). Archiv für Hydrobiologie 86: 423-444. 


\section{Limnology of Kandy Lake}

Schiemer, F., U.S. Amarasinghe, J. Frouzova, B. Sricharoendhaam \& E.I.L. Silva 2001.

Ecosystem structure and dynamics - a management basis for Asian reservoirs and Lakes. In: Reservoir and Culture-Based Fisheries: Biology and Management (S.S. De Silva ed). pp. 226-235, ACIAR Proceedings 98, Australian Centre for International Agricultural Research, Canberra.

Sharaff, F.F. 2003.

Investigation on the State of Pollution and the Bacterial Consortia of Surface Water in Kandy Lake, M.Sc. Thesis, University of Kelaniya. 118 p.

Silva, E.I.L. \& R.W. Davies 1986.

Primary productivity and related parameters in three different types of inland waters in Sri Lanka. Hydrobiologia 137: 239-249.

Silva, E.I.L. \& R.W. Davies 1987.

The seasonality of monsoonal primary productivity in Sri Lanka. Hydrobiologia 150: 165 - 175.

Silva E.I.L. \& F. Schiemer 2001.

Human Factor: Fourth Dimension of Limnology in the Tropics. In: Reservoir and Culture-Based Fisheries: Biology and Management (S.S. De Silva ed.). pp. 111-125, ACIAR Proceedings 98, Australian Centre for International Agricultural Research, Canberra.

Silva, E.I.L., U.S. Amarasinghe, S.S. De Silva, C. Nissanka \& F. Schiemer 2002.

Some aspects of photosynthetic characteristics in a set of perennial irrigation reservoirs located in five river basins in Sri Lanka. Hydrobiologia 485: 19-33

Silva, E.I.L. \& S.R.M.S Samaradiwakara, 2004.

Limnology of Kandy Lake before the outbreak of cyanaobacteria bloom I. Physicochemical limnology. Sri Lanka Journal of Aquatic Sciences 9: 69-89.

Skulberg, O.M., G.A. Codd \& W.W. Carmichael 1984.

Toxic blue-green algal bloom in Europe: a grazing problem. Ambio 13: 244-247.

Straškraba M. \& Tundisi, J.G. 1999.

Guidelines of Lake Management Vol.9. Reservoir Water Quality Management International Lake Environment Committee.

Talling, J.F., 1965.

The photosynthetic activity of phytoplankton in East African lakes. Internationale Revue der gesamten Hydrobiologie 50: 1-32.

Talling, J.F. \& J. Lemoalle 1998.

Ecological Dynamics of Tropical Inland Waters. Cambridge University Press. 441 p. 
Thornton, J. F. (ed.) 1990.

Lake McIlawaine: The Eutophication and the Recovery of a Tropical African Man-made Lake. Mongraphie Biologicae 49. W. Junk Publishers, The Hague.

Vincent, W.F. 1979.

Mechanisms of rapid photosynthetic adaptation in natural phytoplankton communities. Journal of Phycology 15: 429-433.

Ward, A.K. \& R.G. Wetzel 1980.

Photosynthetic response of blue-green algal populations to variable light intensities. Archiv für Hydrobiolologie 90: 129-138.

Wissamar, R.C., J.E. Richie, R.F. Stallard \& J.M. Edmond 1981.

Plankton Metabolism and carbon processes in the Amazon river, its tributaries and floodplain waters, Peru-Brazil, May-June 1977. Ecology 62: 1622-1633. 